\title{
Serum Lead Level in Children with Acute Leukemia
}

\author{
TASNIM AHMED ${ }^{1}$, AK M AMIRUL MORSHED ${ }^{2}$, TASRINA RABIA CHOUDHURY ${ }^{3}$, MD. SHAHIDUR \\ RAHMAN KHAN ${ }^{4}$, MARIUM BEGUM ${ }^{5}$
}

\begin{abstract}
Background: Lead toxicity is one of the most frequently reported unintentional toxic heavy metal exposures and the leading cause of single metal toxicity in children. Lead has no known beneficial function in human metabolism, rather its exposure has various detrimental effect on child health. Lead exposure causes activation of several cellular and molecular processer in leukemic cells so the purpose of the study was to measure serum concentration of lead in newly diagnosed acute lymphoblastic leukemia (ALL) patients.
\end{abstract}

Methodology: The study group consisted of newly diagnosed ALL patients ranging from 2 to 12 years who were admitted at the Department of Pediatrics in Dhaka Medical College Hospital (DMCH), from February 2013 to January 2014 and age and sex matched healthy children's were selected as controls. Serum measurements for lead were performed by Atomic absorption spectrophotometer in Analytical Chemistry Laboratory of Atomic Energy Centre Ramna, Dhaka.

Results: The ALL group composed of 30 patients and 33 healthy children in the control group. There was no significant difference in the age $(p=0.781)$ and sex $(p=0.572)$ of the two groups. The mean serum lead level of ALL patient group $(234.8 \pm 162.9 \mu \mathrm{g} / \mathrm{L})$ was significantly higher than that of the control group $(23.6 \pm 12.6$ $\mu g / L)$. There was significant difference of serum lead level in children with $A L L$ and control group $(p<0.05)$.

Conclusion: Serum lead (PB) level was significantly raised in acute lymphoblastic leukemia patients.

Key words: Acute Lymphoblastic Leukemia, Lead, ALL

\section{Background}

Lead toxicity is one of the most frequently reported unintentional toxic heavy metal exposures and the leading cause of single metal toxicity in children. ${ }^{1}$ Exposure to lead which is a carcinogen is known to be involved in the pathogenesis of many disease including hematological malignancy. It is not possible

1. Assistant Professor, Department of Pediatrics, Basundhara Ad-din Medical College Hospital, Dhaka

2. Professor and Head of the department, Paediatric Hematology \& Oncology Department, Dhaka Medical College Hospital, Dhaka

3. Senior scientific Officer, Chemistry division, Atomic Energy Centre, Dhaka

4. Junior experimental Officer, Chemistry division, Atomic Energy Centre, Dhaka.

5. Associate Professor, Department of Pediatrics, Bashundhara Ad-din Medical college Hospital

Correspondence: Dr. Tasnim Ahmed, Assistant Professor, Department of Pediatrics, Bashundhara Ad-din Medical college Hospital, Phone: 01711229836, E-mail: tasnim.ahmed16 @yahoo.com

Received: 14 October 2017

Accepted: 13 March 2018 to completely avoid exposure to toxic metals. Even people who are not occupationally exposed carry certain metals in their body as a result of exposure from other sources, such as food, beverages, or air. It has no known beneficial function in human metabolism. Human environmental exposure is often through lead-containing paint, food stored in lead can liners, food stored in ceramic jars, or contaminated water (pipes cast in lead or soldered using lead solder) .$^{2}$ Inhalation of lead is a primary route of occupational lead exposure, while oral ingestion is a primary form of exposure in the general population. ${ }^{3}$ Children absorb lead up to 8 -times more efficiently than adults. ${ }^{4}$ Ingestion of deteriorating lead-based paint chips or dust is the primary source of lead exposure in children. ${ }^{5}$ Also, toys and other children's products may contain lead or be painted with lead-based paint; Conditions that cause release of calcium from the bones (fracture, pregnancy, age-related bone loss) will 
also release stored lead from bones, thus allowing it to enter into the blood and other organs. Lead can leave the body through feces or urine. ${ }^{6}$ In children, low level $(<10 \mu \mathrm{g} / \mathrm{dL})$ lead exposure can result in several developmental disorders (accelerated skeletal growth, cognitive deficits, distractability, attention deficit hyperactive disorder and IQ decline ${ }^{4}$, slowed growth and delayed sexual maturation) and higher levels (around 60-100 $\mu \mathrm{g} /$ $\mathrm{dL}$ ) can manifest as colic. ${ }^{6}$

Children are particularly sensitive to lead intoxication, both acute and chronic, and there is no identified safe level of lead exposure in children. ${ }^{5}$ Some studies showed that serum lead level were higher in ALL patients. ${ }^{13}$ A study in Turkey found that serum lead level were significantly elevated in ALL patients. ${ }^{13}$ In Bangladesh there are insufficient data regarding lead and other trace elements exposure and their consequences. So this study was done to assess the level of lead in ALL patients.

\section{Methods}

This Case-control study was conducted in Pediatric Hematology \& Oncology Department of Dhaka Medical College Hospital over a period of one year from February 2013 to January 2014. In this study, 30 ALL patients were enrolled. Patients who were newly diagnosed and treatment was not started were taken as cases. Seriously ill patients were excluded. Thirty-three age and sex matched healthy children coming from same socio economic condition and having same dietary habit, attending outpatient department along with guardians were taken as controls. Regarding residence both patients and controls were from all over the country as it is a tertiary care hospital. Consent were obtained from their parents. Data were collected by researcher himself in a pre-designed questionnaire. Physical examination was done to exclude any other illness. Blood samples $(3 \mathrm{~mL})$ were drawn from patients by aseptic way \& then allowed to stand for 15-30 minutes for formation of clot. Then it was centrifuged and the supernatant fluid was separated by pipette, kept in appendrop and used for serum lead determination. For long term storage specimens were kept below $20^{\circ} \mathrm{C}$ and a lot of $15-20$ samples together were supplied at a time to the Analytical Chemistry Laboratory, Chemistry Division of Atomic Energy Centre, Ramna. Serum lead status was measured using flame atomic absorption spectrometry method (atomic absorption spectrophotometer, model no: Varian AA 240FS, USA). Serum samples were diluted (1:1) with de-ionized water. The viscosity of the diluted serum samples were then matched effectively with the working standard solution. The working standard solution was prepared by diluting a stock solution containing $1000 \mathrm{mg} / \mathrm{L}$ of single element. Atomic absorption spectrometer (AAS) grade standard with ultra-pure water and $5 \%$ glycerin. A Varian (Varian, DuoAA240FS and AA280Z) atomic absorption spectrophotometer (AAS) equipped with fully integrated atomizers (viz. a burner system for flame atomization) used for doing analysis.

\section{Results}

It was observed that majority $19(63.3 \%)$ in case group and 22(66.7\%) patients in control group belonged to age 2-6 years respectively. Male was found $17(56.7 \%)$ in case group and $19(63.3 \%)$ in control group. Female was $13(43.3 \%)$ in case group and $11(36.7 \%)$ in control group. The difference was not statistically significant $(p>0.05)$ between two groups as table I illustrated.

Table-I

Demographic variables among the study population $(n=63)$

\begin{tabular}{lcccc}
\hline $\begin{array}{l}\text { Demographic } \\
\text { variable }\end{array}$ & $\begin{array}{c}\text { Case } \\
(\mathrm{n}=30)\end{array}$ & & $\begin{array}{c}\text { Control } \\
(\mathrm{n}=33)\end{array}$ & $\begin{array}{c}\mathrm{P} \\
\text { value }\end{array}$ \\
\cline { 2 - 3 } & $\mathrm{N}$ & $\mathrm{n} \%$ & \\
\hline
\end{tabular}

Age (years)

$\begin{array}{llllll}2-6 & 19 & 63.3 & 22 & 66.7 & 0.781^{\text {ns }}\end{array}$

$\begin{array}{lllll}7-12 & 11 & 36.7 & 11 & 33.3\end{array}$

Sex

$\begin{array}{llllll}\text { Male } & 17 & 56.7 & 21 & 63.6 & 0.572^{\text {ns }}\end{array}$

$\begin{array}{lllll}\text { Female } & 13 & 43.3 & 12 & 36.4\end{array}$

Socio-economic condition

\begin{tabular}{lccccl} 
Surplus & 0 & 0.0 & 0 & 0.0 & \\
Balance & 9 & 30.0 & 11 & 33.3 & $0.776^{\mathrm{ns}}$ \\
Deficit & 21 & 70.0 & 22 & 66.7 & \\
\hline
\end{tabular}

Table II shows history of the patients. It was observed that $21(70.0 \%)$ patients had fever, $17(56.7 \%)$ had generalized weakness, $13(43.3 \%)$ had pallor, $14(46.7 \%)$ had bleeding manifestation. Majority $6(20.0 \%)$ patients had skin bleeding manifestation. 
Table-II

Clinical features of cases $(n=30)$

\begin{tabular}{lcc}
\hline History & No. of patients & Percentage \\
\hline ALL in family & 0 & 0.0 \\
Fever & 21 & 70.0 \\
Generalized weakness & 17 & 56.7 \\
Pallor & 13 & 43.3 \\
Bleeding manifestation & 14 & 46.7 \\
Site & & \\
$\quad$ Skin & 6 & 20.0 \\
$\quad$ Gum bleeding & 4 & 13.3 \\
$\quad$ Epistaxis & 1 & 3.3 \\
$\quad$ Hematemesis & 1 & 3.3 \\
$\quad$ Melena & 2 & 6.7 \\
\hline
\end{tabular}

Table III shows physical examination of the patients. It was observed that $15(50.0 \%)$ patients had anaemia, $8(26.7 \%)$ had palpable lymph nodes, $8(26.7 \%)$ had purpuric rash, $20(66.7 \%)$ had palpable liver, $18(60.0 \%)$ had palpable spleen.

Table -III

Physical findings in case group $(n=30)$

\begin{tabular}{lcc}
\hline Physical examination & No. of patients & Percentage \\
\hline Anaemia & 15 & 50.0 \\
Palpable lymph nodes & 8 & 26.7 \\
Purpuric rash & 8 & 26.7 \\
Palpable liver & 20 & 66.7 \\
Palpable spleen & 18 & 60.0 \\
\hline
\end{tabular}

Table IV shows serum lead level of the patients. It was observed that normal $(<100 \mu \mathrm{g} / \mathrm{L})$ serum level was $5(17.0 \%$ ) in case group and $33(100.0 \%)$ in control group. Mean serum lead level was found $234.8 \pm 162.9 \mu \mathrm{g} / \mathrm{L}$ in case group and $23.6 \pm 12.6$ $\mu \mathrm{g} / \mathrm{L}$ in control group. The difference was statistically significant $(p<0.05)$ between two groups.
Table-IV

Serum lead level of the study population $(n=63)$

\begin{tabular}{|c|c|c|c|c|c|}
\hline \multirow[t]{2}{*}{$\begin{array}{l}\text { Serum lead } \\
\text { level }(\mu \mathrm{g} / \mathrm{L})\end{array}$} & \multicolumn{2}{|c|}{$\begin{array}{l}\text { Case } \\
(n=30)\end{array}$} & \multicolumn{2}{|c|}{$\begin{array}{l}\text { Control } \\
(n=33)\end{array}$} & \multirow[t]{2}{*}{$\begin{array}{c}\mathrm{P} \\
\text { value }\end{array}$} \\
\hline & $n$ & $\%$ & $n$ & $\%$ & \\
\hline$<100$ & 5 & 17.0 & 33 & 100.0 & \\
\hline $100-200$ & 13 & 43 & 0 & 0.0 & \\
\hline$>200$ & 12 & 40.0 & 0 & 0.0 & \\
\hline Mean \pm SD & \multicolumn{2}{|c|}{$234.8 \pm 162.9$} & \multicolumn{2}{|c|}{$23.6 \pm 12.6$} & $0.001^{\mathrm{s}}$ \\
\hline Range (min-max) & \multicolumn{2}{|c|}{$(39.9-602)$} & \multicolumn{2}{|c|}{$(20-75)$} & \\
\hline
\end{tabular}

ns=significant

$P$ value reached from unpaired t-test

\section{Discussion}

The present study focused on the serum lead level in acute lymphoblastic leukemia patients admitted in Department of Pediatric Hematology \& Oncology, Dhaka Medical College and Hospital. In this case control study a total of 63 children were included. Of them 30 child were patients and 33 healthy control. Age and sex matched healthy children who had no major illness were taken as control population.

It was observed that majority $19(63.3 \%)$ in case group and $22(66.7 \%$ ) patients in control group belonged to age 2-6 years respectively. The difference was not statistically significant $(p>0.05)$ between two groups. Begum ${ }^{7}$ showed that the mean age of ALL was about $6 \pm 3.32$ years Similarly, Margolin, et al. ${ }^{8}$ and Link and Weinstein ${ }^{9}$ found almost similar age range in their study. The above findings are comparable with the current study.

It was observed that male was found $17(56.7 \%)$ in case group and $19(63.3 \%)$ in control group. Female was $13(43.3 \%)$ in case group and $11(36.7 \%)$ in control group. The difference was not statistically significant $(p>0.05)$ between two groups. Sabina and Antonella ${ }^{10}$ showed male to female ratio of 1.25 with an overall male gender prevalence in their study. The above findings are comparable with the current study.

It was observed that balance socio-economic condition was found $9(30.0 \%)$ in case group and $10(33.3 \%)$ in control group. Deficit socio-economic condition was $21(70.0 \%)$ in case group and $20(66.7 \%)$ in control group. The difference was not statistically significant $(p>0.05)$ between two groups. Alexander FE and Ricketts $T \mathrm{~J}^{11}$ In their study described that there is no effect of socio-economic condition on ALL patients 
and their survival and that is comparable with the current study.

Demir $\mathrm{C}$ showed that serum $\mathrm{Cu}, \mathrm{Pb}$ and $\mathrm{Cd}$ were significantly elevated $(p=0.003, p<0.001, p<0.001$, respectively) in ALL patients ${ }^{12}$.M.K.Schwartz revealed serum $\mathrm{Pb}$ concentration were high in serum of acute leukemia compared to the control group ${ }^{13}$. However $\mathrm{Pb}$ was insignificantly elevated $(p=0.381)$ in another study ${ }^{14}$.

\section{Conclusion:}

In conclusion this study revealed that serum lead (pb) level was significantly high in acute lymphoblastic leukemia patients.

\section{References}

1. Bronstein, A. C., Spyker, D. A., Cantilena, L. R., Jr, Rumack, B. H., and Dart, R. C. 2011 Annual Report of the American Association of Poison Control Centers, National Poison Data System (NPDS): 29th Annual Report. ClinToxicol (Phila). 2012;50(10):911-1164

2. Clement G. Yedjou, Jessica N. Milner, Carolyn B. Howard, and Paul B. Tchounwou Basic Apoptotic Mechanisms of Lead Toxicity in Human Leukemia (HI-60) Cells. Int J Environ Res Public Health. 2010;7(5):2008-2017.

3. Rodrigues EG, Virji MA, McClean MD, Weinberg J, Woskie S, Pepper LD. Personal exposure, behavior, and work site conditions as determinants of blood lead among bridge painters. J Occup Environ Hyg. 2010;7(2):80-7

4. Abelsohn AR, Sanborn M. Lead and children: clinical management for family physicians. Can Fam Physician. 2010;56(6):531-5
5. CDC. Centers for Disease Control.Fourth National Report on Human Exposure to Environmental Chemicals. 2009;1-529

6. ATSDR. Toxicological Profile For Lead. 2007b;1582. Available online at http://www.atsdr.cdc.gov/ toxprofiles/tp13.pdf accessed on 29/10/2013

7. Begum HA. Childhood Cancer Registry in Dhaka: Nineteen Months Report. Bangladesh J of Child Health 1985;9(2):90-97.

8. Margolin JF, Steuber CP \&Poplack DG.Acute Lymphoblastic Leukemia. In: Pizo PA \&Poplack DG eds. Principles and Practice of Pediatric Oncology, pp 514-584. Philadelphia: LippincottWilliams \& Wilkins 2005.

9. Link MP \& Weinstein HJ. Malignant Non-Hodgkin Lymphomas in Children, In: Philip AP and David GP ed. Principles and practice of Pediatric Oncology, pp 624-625. Philadelphia: LippincottWilliams \& Wilkins 2005.

10. Sabina Chiaretti, Antonella Vitale, Gianni Cazzaniga, Sonia Maria.Clinico-Biological Features Of 5202 Patients With Acute Lymphoblastic Leukemia Enrolled In The Italian AIEOP And GIMEMA Protocols And Stratified In Age CohortsHaematologica 2013;98: 1702-1710.

11. Alexander F E, Ricketts T JMcKinney PACart wright RA. Community lifestyle characteristics and risk of acute lymphoblastic leukaemia in children, Lancet, 1990; 336(8729):1461-5.

12. Demir $C$, Demir $H$, Esen $R$, Sehitogullari $A$, Atmaca M, Alay M : Altered serum levels of elements in acute leukemia cases in Turkey, Asian Pac J Cancer Prev. 2011;12(12): 3471-4.

13. M. K. Schwartz, Role of trace elements in cancer, Cancer Res.1975;35:3481-3487. 